\title{
Electrocardiographic abnormalities in children with idiopathic scoliosis
}

\author{
J Durmala ${ }^{1 *}$, M Sosnowska², M Sosnowski ${ }^{2}$ \\ From 8th International Conference on Conservative Management of Spinal Deformities and SOSORT 2011 \\ Annual Meeting \\ Barcelona, Spain. 19-21 May 2011
}

\section{Background}

Cardiac involvement in the natural history of Idiopathic Scoliosis (IS) is not uncommon. We aimed at assessment of ECG abnormalities in a relatively large population of children with IS.

\section{Materials and methods}

303 children, hospitalized in our Department, were examined. There were 260 girls and 43 boys, aged $14.2 \pm 0.2$ and $14.1 \pm 0.4$ years. Children with a certain diagnosis of cardiovascular disease were excluded. All patients had clinical and radiological evaluation. A routine ECG was recorded during in-hospital stay and analyzed for the presence of abnormal values/patterns in respect to age, gender and scoliosis gravity.

\section{Results}

Any ECG abnormalities were found in 166 children (55\%). In most of them 1 abnormal value/feature was seen (118, $39 \%$ ), in 42 at least $2(14 \%)$, and in 6 children $>2$ ECG pathologies were found (2\%). The rsr' pattern was most frequent $(128,42 \%)$. RVH was seen in 7 children $(2 \%)$, LVH in $12(4 \%)$ and LAE in $4(1 \%)$. In 11 children (4\%) abnormal HR was found, prolonged PR in 12 (4\%), prolonged QRS in $23(8 \%)$ and prolonged QTc in $1(0.3 \%)$. P-wave axis deviation (11, 4\%), QRS axis deviation (7, 2\%), $\mathrm{T}$-wave axis deviation $(2,1 \%)$ and abnormal ventricular gradient $(9,3 \%)$ were also noticed. Presence of the ECG abnormalities did not depend on age, gender and the number or gravity of curvatures.

\section{Conclusions}

There are number of abnormal ECG parameters in children with IS. Most of them are benign or negligible.

${ }^{1}$ School of Health Care Katowice, Poland

Full list of author information is available at the end of the article
More serious ECG abnormalities is uncommon, however, their presence should be more deeply evaluated.

\section{Author details \\ ${ }^{1}$ School of Health Care Katowice, Poland. ${ }^{2}$ School of Medicine, Medical University of Silesia, Katowice, Poland.}

Published: 27 January 2012

\section{References}

1. Liu L, Xiu P, Li Q, Song Y, Chen R, Zhou C: Prevalence of cardiac dysfunction and abnormalities in patients with adolescent idiopathic scoliosis requiring surgery. Orthopaedics 2010, 33(12):882, Doi: 10.3928/ 01477447-20101021-08

2. Durmala J, Sosnowska M, Sosnowski M: Prevalence of subtle cardiac electrical abnormalities in chilfren with idiopathic scoliosis. Stud Health Technol Inform 2006, 123:425-30.

doi:10.1186/1748-7161-7-S1-O21

Cite this article as: Durmala et al.: Electrocardiographic abnormalities in children with idiopathic scoliosis. Scoliosis 2012 7(Suppl 1):O21.

Submit your next manuscript to BioMed Central and take full advantage of:

- Convenient online submission

- Thorough peer review

- No space constraints or color figure charges

- Immediate publication on acceptance

- Inclusion in PubMed, CAS, Scopus and Google Scholar

- Research which is freely available for redistribution

\section{Biomed Central}

(c) 2012 Durmala et al; licensee BioMed Central Ltd. This is an open access article distributed under the terms of the Creative Commons Attribution License (http://creativecommons.org/licenses/by/2.0), which permits unrestricted use, distribution, and reproduction in any medium, provided the original work is properly cited. 